\title{
Cooking methods affect eating quality, bio-functional components, antinutritional compounds and sensory attributes of selected vegetables
}

\author{
Nusrat Maqbool ${ }^{1}$, Sajad Ahmad Sofi ${ }^{1}$, Hilal A. Makroo ${ }^{1}$, Shabir A. Mir ${ }^{2}$, Darakshan Majid ${ }^{1 *}$ and B.N. Dar $^{1 *}$ \\ ${ }^{1}$ Department of Food Technology, Islamic University of Science E Technology, India; ${ }^{2}$ Department of Food Science E \\ Technology, Government College for Women, M. A. Road, Srinagar, Jammu and Kashmir, India
}

*Corresponding Authors: B.N. Dar, Department of Food Technology, Islamic University of Science \& Technology, India. Email: darnabi@gmail.com. Darakshan Majid, Department of Food Technology, Islamic University of Science \& Technology, India. Email: syed.darakshan@gmail.com

Received: 19 June 2021; Accepted: 10 October 2021; Published: 5 November 2021

(c) 2021 Codon Publications

OPEN ACCESS (C)

PAPER

\begin{abstract}
The study aimed to evaluate the effect of boiling, air-frying and microwave methods of cooking on the phytochemical and antinutritional activity of some vegetables. Total phenolic content was the highest in kale $(9.70 \mathrm{mg}$ GAE/g) using air frying and in carrot using microwave ( $9.15 \mathrm{mg} \mathrm{GAE} / \mathrm{g}$ ) and boiling (5.16 $\mathrm{mg} \mathrm{GAE} / \mathrm{g}$ ) methods. The cooking of vegetables for $15 \mathrm{~min}$ of air frying depicted a significant increase in total flavonoids. Oxalate content in vegetables were significantly reduced by air frying, tannins by boiling and saponin in microwave cooking. A significant decrease in oxalate content was observed in kale by air frying and boiling methods, in carrot by microwave cooking, and reduction in tannins in tomatoes by air frying and boiling methods.
\end{abstract}

Keywords: antinutrients, beans, cooking, kale, phytochemicals, spinach

\section{Introduction}

In recent years, consumption of food with bioactive ingredients with nutraceutical potential has increased in consumer diet. Vegetables are one of the natural foods associated with numerous healthy ingredients and are recommended as a part of a healthy lifestyle for end users. Vegetables, consumed as raw, cooked or in processed form, are parts of fresh plants which provide nutrition to humans (Groch, 2008). Consumption of vegetables in the human diet is associated with health benefits because of immunoregulatory and antioxidant properties to fight inflammatory, allergic, atherogenic, microbial, thrombotic, cardiovascular diseases, cancer and diabetes (Rashmi and Negi, 2020). Vegetables are a rich source of fibers, vitamins, minerals and phenolic components (Septembre-Malaterreb et al., 2018). The presence of bioactive nutrients in vegetables is associated with health benefits to fight chronic diseases (Eliassen et al., 2012;
Pojer et al., 2013). Phytochemicals, such as flavonols, isoflavones, phenolic acids, flavones, and carotenoids, present in vegetables have demonstrated antioxidant, anti-inflammatory and antitumor effects (SeptembreMalaterreb et al., 2018). Besides phytochemicals, there are secondary metabolites such as antinutrients with a detrimental effect on nutrients and sensory properties of vegetables. Antinutrients most commonly present in vegetables are lectins, tannins, phytic acids, saponins, phytates, glucosinolates, cyanogens and phytoalexins, with reduced bioavailability of essential components and inhibition of digestive enzyme activity (SeptembreMalaterreb et al., 2018; Kaur et al., 2015).

Kale, a leafy and nutritionally important vegetable of the family Brassica, is consumed in different parts of the world (Singh et al., 2009). Kale is a good source of ascorbic acid, carotenoids, flavonoids and polyphenol-rich compounds with health-promoting phytochemicals having reduced 
risk of heart disease, cancers and diabetes (Chenard et al., 2015; Ferioli et al., 2013; Korus and Lisiewska, 2011).

Spinach is a nutritious leafy vegetable containing a good amount of vitamins, dietary fiber, minerals and polyunsaturated fatty acid, a therapeutic ingredient used against arthritis, obesity, cancer, osteoporosis and anemia (Bassey and Khan, 2015; Patricia et al., 2014).

Beans belong to the family Fabaceae and are rich in proteins, starch, dietary fiber, minerals and vitamins (Siddiq et al., 2010). Beans have been associated with many health benefits because of dense and rich ingredients such as flavonoids, phenolic acids and isoflavones (Aparicio-Fernandez et al., 2005; Granito et al., 2008; Lin et al., 2008; Chung et al., 2008).

Carrots are one of the most important vegetables with a potentially rich source of carbohydrates, minerals and carotenoids with anticarcinogenic, antioxidants, and immune-boosting properties (Fiedor and Burda, 2014; Tanaka et al., 2012).

Tomato is a globally cultivated fleshy vegetable with dense and rich nutritive components, including vitamins, minerals and phytochemicals that impart health benefits (Frusciante et al., 2007). Tomato usage in the diet has been related to the reduction of inflammatory risk processes, cancer, cardiovascular disease, hypertension, diabetes and obesity (Adams et al., 2011.

Vegetables with health beneficial ingredients are primarily consumed after processing using different cooking methods with aim of enhancing palatability, digestibility and taste. Cooking treatment induces physical and chemical changes, structure, nutritional quality and texture of vegetables (Rehman et al., 2003; Tepe and Ekinci, 2021). It also induces cell wall permeability and increases the extraction of phytochemicals and reduction in antnutrients (Rodriguez-Amaya, 1999). A significant loss of vitamins and phytochemicals has been observed during the cooking of vegetables that varies with different cooking methods (Lin and Chang, 2005). Different cooking methods, such as boiling, microwave, steaming, griddled, frying, and baking, affect the structural and nutritional profile of vegetables (Fabbrin and Crosby, 2016; Zhan and Hamauzu, 2004). Oven cooking, air frying, boiling, steaming, microwave treatment, steaming and vacuum cooking are different methods of cooking used for different vegetables to enhance their nutritional profile, bioactive potential, reduce the antinutritional ability and improve sensory acceptability (Fratianni et al., 2021; Nartea et al., 2021; Rana et al., 2021; Rinaldi et al., 2021; Salamatullah et al., 2021; Sun and Ling, 2021). Domestic methods of cooking, such as boiling, air frying and microwave cooking, have increased with an added interest in the phytochemical and antioxidant activity of cooked vegetables. The present study proposes to use optimum time by applying boiling, air frying and microwave methods of cooking, and their effect on phytochemical and antioxidant activity of kale, spinach, beans, carrot and tomatoes.

\section{Material and Methods}

\section{Materials}

Fresh kale (Brassica oleracea var. acephala L.), spinach (Spinacia oleracea L.), beans (Phaseolus vulgaris L.), carrot (Daucus carota L.) and tomatoes (Solanum lycopersicum L.) were purchased from the vegetable market of Kashmir Valley. After proper removal of post-harvest nonedible parts, the edibles were soaked in clean water $\left(25^{\circ} \mathrm{C}, \mathrm{pH} 7\right)$, dried and diced into uniform slices. The dried vegetables were subsequently divided into four parts and treated with boiling, air frying and microwave cooking method.

\section{Cooking Treatments}

Boiling: Vegetable samples (100 g) were boiled at $100^{\circ} \mathrm{C}$ in a stainless steel pan with $150-\mathrm{mL}$ distilled water for 2 , 4 and 6 min until it becomes tender.

Air frying: Vegetable samples $(100 \mathrm{~g})$ were fried at $200^{\circ} \mathrm{C}$ in an air fryer with $5 \mathrm{~mL}$ of hot refined oil for 7.5, 10 and $15 \mathrm{~min}$.

Microwave: Vegetable samples (100 g) were micro-cooked in $150 \mathrm{~mL}$ of water at $800-\mathrm{W}$ power for $1,2.5$ and $5 \mathrm{~min}$.

The cooking was followed by an afterward tempering period of a few minutes at room temperature. The tempered samples were subjected to homogenization in a blender. The homogenized samples were packed in polyethene pouches, sealed and stored at $-20^{\circ} \mathrm{C}$ for further analysis.

\section{Proximate analysis}

The proximate composition of vegetable samples was determined according to standard procedures of the Association of Official Analytical Chemists (AOAC, 2002) for moisture (method 925.09), fat (method 920.39), protein (method 955.04), crude fiber (method 962.09) and ash content (method 991.43).

\section{Phytochemical and antioxidant activity of vegetables}

\section{Preparation of extract}

Homogenized vegetable samples, 2 g, were extracted with $80 \%$ methanol $(50 \mathrm{~mL})$. Then centrifugation of 
samples was performed at 2,200 rpm for $15 \mathrm{~min}$ at room temperature. The decanted supernatant was stored at $4^{\circ} \mathrm{C}$ for determining total phenolic content, total flavonoid content and antioxidant activity of vegetable samples.

\section{Total phenol content}

The total phenolic content of vegetable samples was determined according to the method demonstrated by Singleton et al. (1999). A sample extract of $0.2 \mathrm{~mL}$ was treated with Folin Ciocalteu reagent $(1 \mathrm{~mL})$. After $3 \mathrm{~min}$, the reaction mixture was added with $20 \%$ sodium carbonate solution $(0.80 \mathrm{~mL})$ and stirred properly and incubated for $2 \mathrm{~h}$ at ambient temperature. The absorbance value of the reagent mixture was measured at a wavelength of 725 nm using an ultraviolet-visible spectroscopy (UV/VIS) (UV-1700 Spectrophotometer, Japan). The results were expressed as mg GAE/g using gallic acid as standard.

\section{Total flavonoid content}

The total flavonoid content of cooked vegetables was measured by the method described by Ebrahimzadeh et al. (2008). A sample extract of $2 \mathrm{~mL}$ was mixed with $10 \%$ aluminium chloride $(100 \mu \mathrm{L})$, followed by the addition of $1 \mathrm{~N}$ potassium acetate $(100 \mu \mathrm{L})$. The reagent mixture was diluted with $2.8 \mathrm{~mL}$ of distilled water. The sample mixture was incubated at room temperature for $30 \mathrm{~min}$ and absorbance was measured at $415 \mathrm{~nm}$. The total flavonoid content was expressed as quercetin equivalent (mg QE/g of sample) using quercetin as standard.

\section{DPPH (2,2-diphenyl-1-picrylhydrazyl) radical scavenging activity}

The DPPH free radical assay was used to determine the antioxidant activity of cooked vegetables as per the method described by Mulla and Ahmed (2019). Sample extract, $100 \mu \mathrm{L}$, was used for antioxidant activity and was added with $1 \mathrm{~mL}$ of $0.01 \% \mathrm{DPPH}$ reagent. The sample mixture was stirred properly and incubated for $30 \mathrm{~min}$ in the dark. Absorbance was measured at $517 \mathrm{~nm}$ after 30 min using a spectrophotometer. The antioxidant activity using free radical scavenging was measured as follows:

Antioxidant acitivity $(\%)=\frac{\text { Abs control }- \text { Abs sample }}{\text { Abs control }} \times 100$

where Abs control = absorbance of control at $30 \mathrm{~min}$, and Abs sample $=$ absorbance of sample solution at $30 \mathrm{~min}$.

\section{Antinutritional component analysis of cooked vegetables}

\section{Oxalate content}

The oxalate content of cooked vegetables was determined using the method described by Ghoora et al. (2020) with minor modifications. Cooked vegetable sample ( $1 \mathrm{~g})$ was treated with $75 \mathrm{~mL}$ of $3-\mathrm{M}$ sulfuric acid, stirred constantly for $1 \mathrm{~h}$, followed by filtering through Whatman filter paper No. 1; 25-mL filtrate aliquot was titrated with potassium permanganate $\left(\mathrm{KMNO}_{4} 0.05 \mathrm{M}\right)$ solution till faint pink color appeared as endpoint. Titration with $1 \mathrm{~mL}$ of $0.05-\mathrm{M} \mathrm{KMNO}_{4}$ is related to $2.2 \mathrm{mg}$ of oxalate (Chinma and Igyor, 2007) and expressed as $\mathrm{mg} / \mathrm{g}$ of oxalate.

\section{Tannin content}

The tannin content in vegetables was analyzed according to the standard procedure of AOAC (2002) with minor modifications. The cooked vegetable sample (3 g) was extracted with distilled water for $4 \mathrm{~h}$ and filtered for tannin analysis. Tannin extract amounting to $25 \mathrm{~mL}$ was treated with $25 \mathrm{~mL}$ of indigo solution. The mixture was diluted with $750 \mathrm{~mL}$ of distilled water and titrated with $0.1-\mathrm{N} \mathrm{KMNO}_{4}$ solution until the blue color of the solution changed to green color. Finally, tannin content in samples was calculated using the following equation:

$\operatorname{Tanin}(\mathrm{mg} / \mathrm{g})=\left(\mathrm{V}-\mathrm{V}_{0}\right) \times 0.004157 \times 250 \times 100 / \mathrm{g} \times 25$,

where $\mathrm{V}$ and $\mathrm{V}_{\mathrm{o}}$ are volume of $0.1-\mathrm{N} \mathrm{KMNO}_{4}$ solution for the titration of sample and blank (without the sample), respectively; 0.004157 is the tannin factor.

\section{Saponin content}

Saponin content in cooked vegetables was determined by the method described by Obadoni and Ochuko (2001). Cooked vegetables ( $3 \mathrm{~g}$ ) were mixed with $20 \%$ aqueous ethanol $(30 \mathrm{~mL})$ with constant stirring for $3 \mathrm{~h}$ on a hot plate. The sample of ethanol mixture was filtered and concentrated, followed by the addition of 10-mL diethyl ether in a separating funnel with vigorous shaking. The separated aqueous part was used and treated with n-butanol $(20 \mathrm{~mL})$. The n-butanol extract was washed twice with $5 \%$ aqueous $\mathrm{NaCl}(10 \mathrm{~mL})$. The remaining solution was heated in a water bath. Finally, the concentrated sample formed after evaporation was dried on a dry bath to a constant weight. The saponin content was expressed using the following equation:

$$
\text { Saponin }(\mathrm{mg} / \mathrm{g})=\frac{\mathrm{w}_{2}-\mathrm{w}_{1}}{\mathrm{w}} \times 100
$$

where $W_{1}$ is the weight of the evaporating disk, $W_{2}$ is the weight of the disk and sample and W is the weight of the sample.

\section{Sensory analysis of cooked vegetables}

The sensory evaluation of cooked vegetables was performed by 15 semi-trained panellists having the basic knowledge of sensory analysis, nutritional interest and 
willingness to participate. The assessment was exercised for color, flavor, taste texture and overall acceptability score using a 5-point hedonic rating scale to generate the following measurable sensory scores: Excellent for a score of 5, Good for a score of 4, Average for a score of 3, Fair for a score of 2 and Poor for a score of 1 .

\section{Statistical analysis}

The experimental data were expressed as mean and standard deviation in triplicate using SPSS Version 16. Phytochemical and antinutritional analyses were performed using one-way ANOVA, followed by Duncan's multiple range tests at a $5 \%$ level of significance.

\section{Results and Discussion}

\section{Proximate composition of fresh vegetables}

The nutrition analysis of fresh vegetables selected for different cooking methods is presented in Table 1 . The selected vegetables differed significantly in nutritional composition. The moisture content of fresh vegetables ranged from 84 to $83 \mathrm{~g} / 100 \mathrm{~g}$. Tomatoes depicted the highest moisture content $(91.60 \mathrm{~g} / 100 \mathrm{~g})$, followed by carrot $(89.30 \mathrm{~g} / 100 \mathrm{~g})$, kale $(88.60 \mathrm{~g} / 100 \mathrm{~g})$, beans $(81.80 \mathrm{~g} / 100 \mathrm{~g})$ and the lowest in spinach $(81.97 \mathrm{~g} / 100 \mathrm{~g})$. The selected fresh vegetables were low in protein content, ranging from 0.86 to $3.93 \mathrm{~g} / 100 \mathrm{~g}$. Beans reported the highest protein content of $3.93 \mathrm{~g} / 100 \mathrm{~g}$ and the lowest was determined in carrot $(0.86 \mathrm{~g} / 100 \mathrm{~g})$. Low fat content was reported in all vegetables, ranging from 0.20 to 0.60 $\mathrm{g} / 100 \mathrm{~g}$. Fiber content in fresh vegetables ranged from 1 to $10 \mathrm{~g} / 100 \mathrm{~g}$, and higher content was observed in spinach $(10.00 \mathrm{~g} / 100 \mathrm{~g})$, followed by beans $(5.00 \mathrm{~g} / 100 \mathrm{~g})$, kale $(4.00 \mathrm{~g} / 100 \mathrm{~g})$, carrot $(3.00 \mathrm{~g} / 100 \mathrm{~g})$ and the lowest in tomatoes $(1.00 \mathrm{~g} / 100 \mathrm{~g})$. Ash content in selected fresh vegetables was the highest in spinach $(2.00 \mathrm{~g} / 100 \mathrm{~g})$, followed by kale (1.60 g/100 g), carrot ( $1 \mathrm{~g} / 100 \mathrm{~g})$, tomatoes $(0.80 \mathrm{~g} / 100 \mathrm{~g})$ and the lowest in beans $(0.10 \mathrm{~g} / 100 \mathrm{~g})$.
Carbohydrate content in selected fresh vegetables varied from 2.05 to $8.97 \mathrm{~g} / 100 \mathrm{~g}$, with the highest reported in beans $(8.97 \mathrm{~g} / 100 \mathrm{~g})$ and the lowest in kale $(2.05 \mathrm{~g} / 100 \mathrm{~g})$. Variations in the nutrient composition of selected vegetables could be due to different agro-climatic conditions (Singh et al., 2001). Results of the nutritional composition of fresh vegetables demonstrated similar results as reported by Naz et al. (2018) and Rani and Fernando (2016).

\section{Effect of cooking methods on phytochemicals of vegetables}

\section{Total phenolic content}

Boiling, air frying and microwave cooking methods depicted increase in the level of total phenolic content of selected vegetables (Figure 1). Among raw vegetables, total phenolic content was reported the highest in tomatoes (2.03 mg GAE/g), followed by carrot (1.97 mg GAE/g), beans (1.69 mg GAE/g), spinach (1.19 mg $\mathrm{GAE} / \mathrm{g}$ ) and the lowest in kale (1.13 mg GAE/g). Boiling time from 2 to 8 min significantly increased the total phenolic content from 4.01 to $5.00 \mathrm{mg} \mathrm{GAE} / \mathrm{g}$ for kale, 3.32 to $4.30 \mathrm{mg} \mathrm{GAE} / \mathrm{g}$ for spinach, 2.07 to $4.01 \mathrm{mg} \mathrm{GAE} / \mathrm{g}$ for beans, 1.76 to $5.60 \mathrm{mg} \mathrm{GAE} / \mathrm{g}$ for carrot and 2.99 to 3.63 $\mathrm{mg} \mathrm{GAE} / \mathrm{g}$ for tomatoes. The air frying of selected vegetables from 7.5 to 15 min reported a significant increase in total phenolic content. Increase in total phenolic content was reported in: kale from 1.60 to $9.70 \mathrm{mg} \mathrm{GAE} / \mathrm{g}$, spinach from 4.84 to $7.47 \mathrm{mg} \mathrm{GAE} / \mathrm{g}$, beans from 6.14 to $8.04 \mathrm{mg} \mathrm{GAE} / \mathrm{g}$, carrot from 2.82 to $5.12 \mathrm{mg} \mathrm{GAE} / \mathrm{g}$ and tomatoes from 5.31 to $6.58 \mathrm{mg}$ GAE/g. Microwave cooking also demonstrated increase in total phenolic content with respect to processing time $(1,2.5$, and $5 \mathrm{~min})$. The total phenolic content of selected vegetables demonstrated an increasing trend with increase in processing time from 1 to $5 \mathrm{~min}$ in microwave cooking. Increase in the total phenolic content of selected vegetables in 1 to 5 min was reported in: kale from 4.31 to $7.78 \mathrm{mg} \mathrm{GAE} / \mathrm{g}$, spinach from 4.45 to $7.24 \mathrm{mg}$ GAE/g, beans from 5.20 to $7.17 \mathrm{mg} \mathrm{GAE} / \mathrm{g}$, carrot from 2.77 to $9.15 \mathrm{mg} \mathrm{GAE} / \mathrm{g}$

Table 1. Proximate composition of vegetables.

\begin{tabular}{lrrrrr}
\multicolumn{5}{c}{ Proximate composition $(\mathbf{g} / \mathbf{1 0 0} \mathbf{g})$} \\
\cline { 2 - 6 } & \multicolumn{1}{c}{ Kale } & \multicolumn{1}{c}{ Spinach } & \multicolumn{1}{c}{ Beans } & \multicolumn{1}{c}{ Carrot } & \multicolumn{1}{c}{ Tomatoes } \\
\hline Moisture & $88.60 \pm 0.10$ & $81.97 \pm 1.00$ & $81.80 \pm 0.01$ & $89.30 \pm 0.10$ & $91.60 \pm 1.00$ \\
Ash & $1.60 \pm 0.02$ & $2.00 \pm 0.10$ & $0.10 \pm 0.69$ & $1.00 \pm 0.15$ & $0.80 \pm 0.01$ \\
Fat & $0.60 \pm 0.01$ & $0.63 \pm 0.01$ & $0.20 \pm 0.39$ & $0.20 \pm 0.39$ & $0.40 \pm 0.01$ \\
Protein & $3.15 \pm 0.02$ & $2.97 \pm 0.01$ & $3.93 \pm 0.02$ & $0.87 \pm 0.01$ & $0.96 \pm 0.01$ \\
Crude Fiber & $4.00 \pm 0.10$ & $10.00 \pm 0.10$ & $5.00 \pm 0.10$ & $3.10 \pm 0.10$ & $1.00 \pm 0.15$ \\
Carbohydrate & $2.05 \pm 0.02$ & $2.43 \pm 0.01$ & $8.97 \pm 0.01$ & $5.53 \pm 0.02$ & $5.24 \pm 0.02$ \\
\hline
\end{tabular}



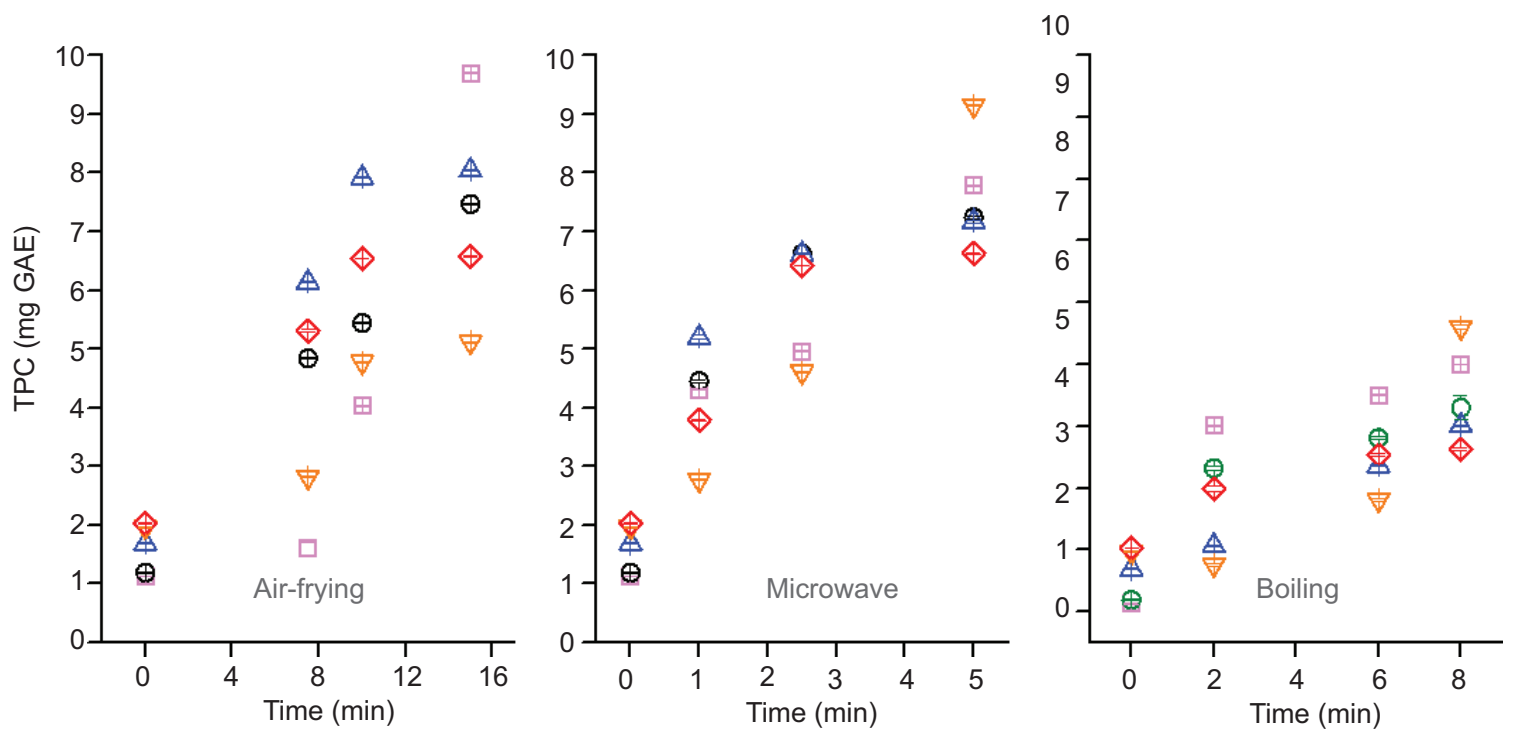

Figure 1. Effect of different cooking methods on the phenolic content (mg GAE/g) of kale $(\square)$, spinach (O), beans $(\triangle)$, carrot $(\nabla)$ and tomatoes $(\diamond)$.

and tomatoes from 3.79 to $6.63 \mathrm{mg} \mathrm{GAE} / \mathrm{g}$. Use of different cooking methods indicated significant improvement in phenolic content of selected vegetables as compared to raw vegetables; however, the use of microwave as a cooking medium significantly increased the total phenolic content of selected vegetables than boiling and air frying methods. The increasing trend of total phenolic content in selected vegetables was due to the release of polyphenols from intracellular complexes during cooking, inactivation of polyphenol oxidase (PPO) enzyme (Oboh, 2005), release of bioactive compounds because of the breakdown of cell walls (Ferracane et al., 2018), and increase in free flavonols (Stewart et al., 2000). Similar findings were also reported in cooked vegetables by Geetha et al. (2018), Hossain et al. (2017) and Saikia and Mahanta (2013).

\section{Total flavonoid content}

The total flavonoid content of selected vegetables is evidenced in Figure 2. Fresh vegetables contained 0.05-0.10 mg QE/g of total flavonoids, and the highest flavonoids were reported in spinach and the lowest in tomatoes and kale. Boiling, air frying and microwave cooking methods reported an increasing trend in total flavonoids content in selected vegetables. The boiling method of cooking with respect to the duration of 2, 6 and 8 min significantly increased the total flavonoids content of vegetables. With increasing boiling time from 2 to $6 \mathrm{~min}$, flavonoids content in: kale was increased from 0.63 to $1.33 \mathrm{mg} \mathrm{QE} / \mathrm{g}$, spinach from 0.15 to $0.78 \mathrm{mg} \mathrm{QE} / \mathrm{g}$, beans from 0.12 to $0.33 \mathrm{mg} \mathrm{QE} / \mathrm{g}$, carrot from 0.04 to $0.27 \mathrm{mg} \mathrm{QE} / \mathrm{g}$ and tomatoes from 0.38 to $0.61 \mathrm{mg} \mathrm{QE} / \mathrm{g}$. The air frying method of cooking demonstrated a significant increase in flavonoid content in kale, spinach and beans than the boiling and microwave methods of cooking. Selected vegetables cooked for 7.5, 10 and $15 \mathrm{~min}$ by air frying method depicted a similar trend of increased flavonoid content. The air frying method with an optimized duration of 7.5-15 min reported an increase in flavonoid content from: 1.35 to $2.41 \mathrm{mg} \mathrm{QE} / \mathrm{g}$ for kale, 0.96 to $2.23 \mathrm{mg} \mathrm{QE} / \mathrm{g}$ for spinach, 0.38 to $1.42 \mathrm{mg} \mathrm{QE} / \mathrm{g}$ for beans, 0.04 to 0.19 $\mathrm{mg} \mathrm{QE} / \mathrm{g}$ for carrot and 0.25 to $0.31 \mathrm{mg} \mathrm{QE} / \mathrm{g}$ for tomatoes. Microwave cooking for a short duration of 1, 2.5 and $5 \mathrm{~min}$ also depicted a similar trend of increased flavonoid content in kale, spinach, beans, carrot and tomatoes (Figure 2). In microwave cooking, at a processing time of $5 \mathrm{~min}$, kale had the highest flavonoid content $(0.97 \mathrm{QE} \mathrm{mg} / \mathrm{g})$, followed by spinach $(0.95 \mathrm{QE}$ $\mathrm{mg} / \mathrm{g}$ ), tomatoes $(0.79 \mathrm{QE} \mathrm{mg} / \mathrm{g})$, carrot $(0.52 \mathrm{QE} \mathrm{mg} / \mathrm{g})$ and the lowest in beans $(0.44 \mathrm{QE} \mathrm{mg} / \mathrm{g})$. A significant increase in the flavonoid content of selected vegetables by different cooking methods is attributed to extracted flavonoid compounds of vegetable matrix and changes in the structure of cell walls of vegetables during cooking (Wachtel-Galor et al., 2008). Variations in the flavonoid content of selected vegetables because of different cooking methods and processing time could be due to differences in the extraction of flavonoids in vegetables, heating medium and duration of cooking. Similar results of increased total flavonoid content in vegetables were reported by Geetha et al. (2018), Mazzeo et al. (2011) and Saikia and Mahanta (2013).

\section{Antioxidant activity}

The reported antioxidant activity of fresh vegetables was the highest in tomatoes (25.90\%), followed by carrot (14.81\%), beans $(11.11 \%)$, kale $(7.40 \%)$ and the lowest in 

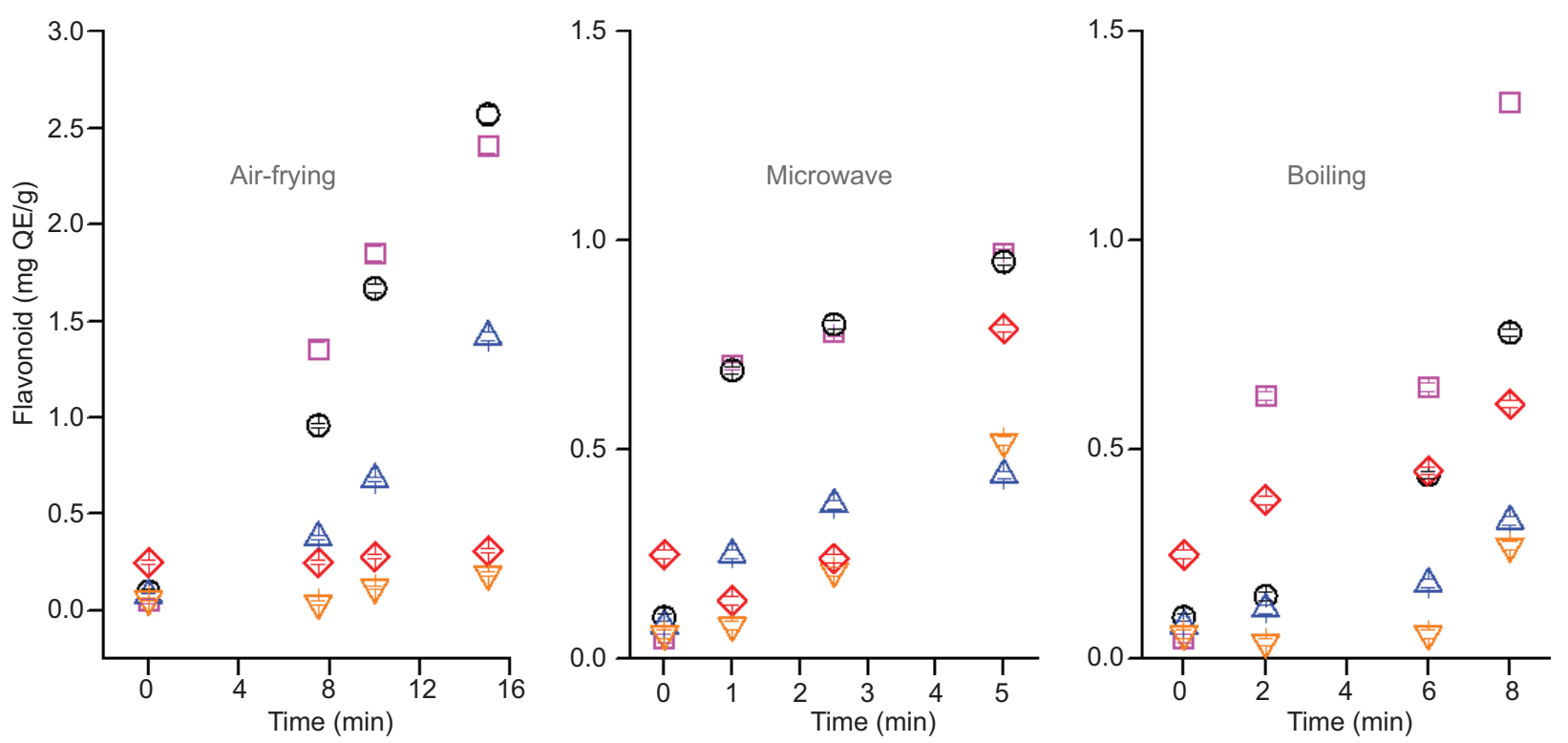

Figure 2. Effect of different cooking methods on the flavonoid content (mg QE/g) of kale $(\nabla)$ and tomatoes $(\diamond)$.

spinach (3.70\%) (Figure 3). The boiling method significantly increased the antioxidant activity of selected vegetables with respect to the optimized cooking time of 2 , 6 and $8 \mathrm{~min}$. The boiling method of cooking for 2-8 min reported a significant increase in the antioxidant activity of kale (18.50-75.10\%), spinach (32.90-85.96\%), beans (27.03-51.85\%), carrot $(42.22-83.70 \%)$ and tomatoes (38.51-97.20\%). Antioxidant activity in selected vegetables differed significantly with respect to optimized time (7.5, 10 and $15 \mathrm{~min})$ in the air frying method of cooking. Antioxidant activity significantly increased from: $7.40 \%$ to $28.14 \%$ for kale, $37.03 \%$ to $55.10 \%$ for spinach, $27.40 \%$ to $43.70 \%$ for beans, $51.80 \%$ to $64.40 \%$ for carrot, and $35.88 \%$ to $67.93 \%$ for tomatoes. The microwave method of cooking established a similar trend of increased antioxidant activity in selected vegetables with respect to optimized processing time (1, 2.5 and $5 \mathrm{~min}$ ) as compared to fresh vegetables. The optimized cooking time of 5 min demonstrated higher antioxidant activity, with the highest of $92.50 \%$ reported in carrot, followed by $91.40 \%$ for beans, $79.25 \%$ for tomatoes, $62.50 \%$ for spinach and $54.07 \%$ for kale. An increase in the antioxidant activity of selected vegetables because of different cooking methods could be due to the Maillard reaction (Saikia and Mahanta, 2013), secondary metabolites (Tayebeh et al., 2021), the release of antioxidant compounds from disrupted cell walls, inhibition of oxidative enzymes and reduced oxidation of antioxidants (Morales and Babel, 2002), and increased phytochemicals during cooking (Zeb et al., 2018). Similar findings were reported by Agamy (2016), Hossain et al. (2017), and Mirzaei et al. (2014).

\section{Effect of cooking methods on antinutritional components of vegetables}

\section{Oxalate content}

Boiling, air frying and microwave cooking evidenced a decrease in the level of oxalate content in selected vegetables as compared to fresh ones (Figure 4). The highest oxalate values in raw vegetables were observed in tomatoes $(6.60 \mathrm{mg} / \mathrm{g})$, followed by spinach $(5.72 \mathrm{mg} / \mathrm{g})$, beans $(3.96 \mathrm{mg} / \mathrm{g})$, kale $(1.58 \mathrm{mg} / \mathrm{g})$ and the lowest in carrot $(1.41 \mathrm{mg} / \mathrm{g})$. Cooking of selected vegetables by boiling significantly reduced oxalate content with respect to the optimized processing time of 2, 6 and 8 min. Reduction in oxalate content was observed in 2-8 min of boiling, varying from 0.88 to $0.22 \mathrm{mg} / \mathrm{g}$ for kale, 3.10 to $1.44 \mathrm{mg} / \mathrm{g}$ for spinach, 4.10 to $2.42 \mathrm{mg} / \mathrm{g}$ for beans, 4.10 to $2.42 \mathrm{mg} / \mathrm{g}$ for carrot and 5.50 to $4.40 \mathrm{mg} / \mathrm{g}$ for tomatoes. Air frying with optimized processing time (7.5, 10 and $15 \mathrm{~min}$ ) also decreased the oxalate content of selected vegetables. Reduction in oxalate content at $15 \mathrm{~min}$ of processing was observed for kale $(0.20 \%), 1.32 \mathrm{mg} / \mathrm{g}$ for spinach, 0.44 $\mathrm{mg} / \mathrm{g}$ for beans, $0.46 \mathrm{mg} / \mathrm{g}$ for carrot and $1.54 \mathrm{mg} / \mathrm{g}$ for tomatoes. The microwave cooking method at a processing time of $1-5$ minutes reduced oxalate content from: 0.77 to $0.44 \mathrm{mg} / \mathrm{g}$ in kale, 2.42 to $0.88 \mathrm{mg} / \mathrm{g}$ in spinach, 4.62 to $2.86 \mathrm{mg} / \mathrm{g}$ in beans, 0.98 to $0.32 \mathrm{mg} / \mathrm{g}$ in carrot and 6.38 to $4.35 \mathrm{mg} / \mathrm{g}$ in tomatoes. In general, cooking methods reduced the oxalate content of vegetables as compared to raw vegetables; however, air-frying and boiling presented significantly higher reductions than microwave cooking. The significant reduction in oxalate content in selected vegetables could be due to leaching 

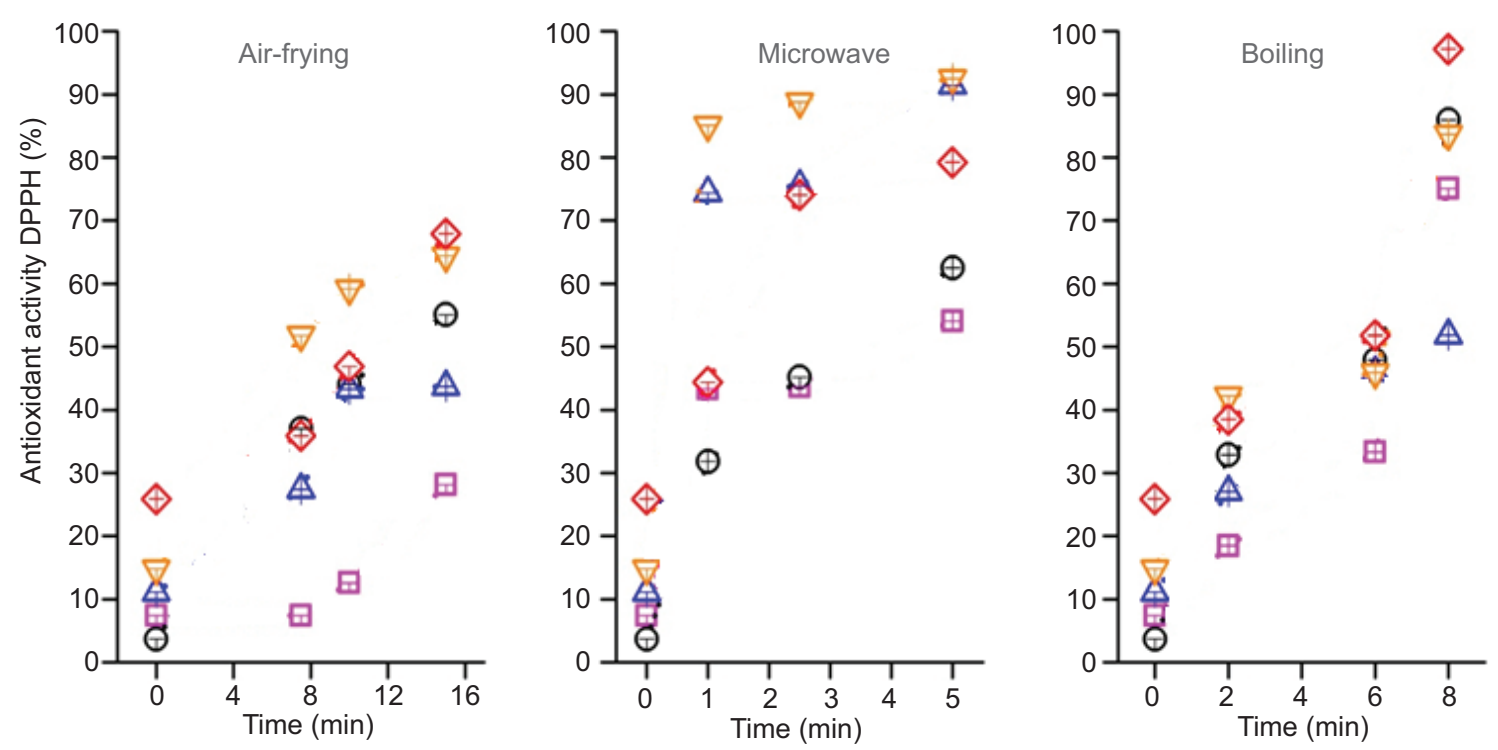

Figure 3. Effect of different cooking methods on the antioxidant activity of kale $(\square)$, spinach $(O)$, beans $(\triangle)$, carrot $(\nabla)$ and tomatoes $(\diamond)$.
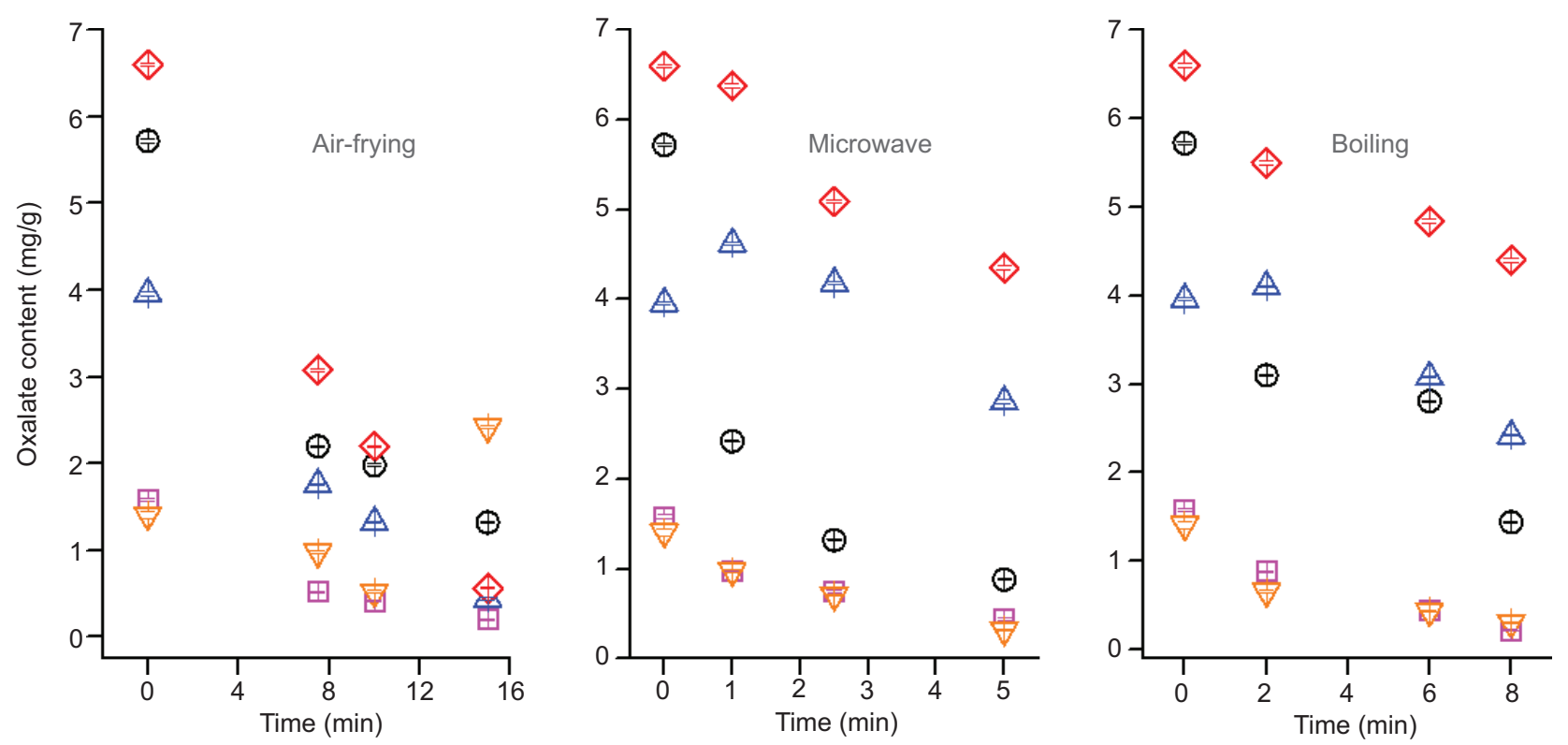

Figure 4. Effect of different cooking methods on the oxalate content of kale $(\square)$, spinach $(O)$, beans $(\triangle)$, carrot $(\nabla)$ and tomatoes $(\diamond)$.

out of soluble oxalate from disrupted tissues during the cooking process (Catherwood et al., 2007; Yadav and Sehgal, 2003). Reduction in oxalate content in cooked vegetables was also observed by Agiriga and Siwela (2018), Akhtar et al. (2014) and Hemmige et al (2017).

\section{Tannin content}

Cooking of vegetables by boiling, air frying and microwave methods significantly reduced $(p<0.05)$ the tannin content as compared to fresh vegetables (Figure 5). The tannin content in fresh vegetables ranged from 6.30 to
$15.4 \mathrm{mg} / \mathrm{g}$. The highest tannin content was observed in beans $(15.4 \mathrm{mg} / \mathrm{g})$, followed by carrot $(10.2 \mathrm{mg} / \mathrm{g})$, spinach $(9.20 \mathrm{mg} / \mathrm{g})$, tomatoes $(8.30 \mathrm{mg} / \mathrm{g})$ and kale $(6.30$ $\mathrm{mg} / \mathrm{g}$ ). The tannin content in cooked vegetables reduced significantly with respect to the optimized processing time for boiling (2, 4 and $6 \mathrm{~min}$ ), air frying $(7.5,10$ and $15 \mathrm{~min}$ ) and microwave cooking (1, 2.5 and $5 \mathrm{~min})$. The reduced tannin content in selected vegetables at $15 \mathrm{~min}$ of boiling was observed as $0.30 \mathrm{mg} / \mathrm{g}$ for kale, $1.20 \mathrm{mg} / \mathrm{g}$ for spinach, $1.20 \mathrm{mg} / \mathrm{g}$ for beans, $1.0 \mathrm{mg} / \mathrm{g}$ for carrot and $0.1 \mathrm{mg} / \mathrm{g}$ for tomatoes. However, air frying for $15 \mathrm{~min}$ and 
microwave for $5 \mathrm{~min}$, respectively, recorded $2.0 \mathrm{mg} / \mathrm{g}$ and $0.1 \mathrm{mg} / \mathrm{g}$ for kale, $1.30 \mathrm{mg} / \mathrm{g}$ and $4.10 \mathrm{mg} / \mathrm{g}$ for spinach, $2.60 \mathrm{mg} / \mathrm{g}$ and $1.20 \mathrm{mg} / \mathrm{g}$ for beans, $1.50 \mathrm{mg} / \mathrm{g}$ and 1.20 $\mathrm{mg} / \mathrm{g}$ for carrot and $1.0 \mathrm{mg} / \mathrm{g}$ and $1.50 \mathrm{mg} / \mathrm{g}$ for tomatoes. The reduction of tannins in cooked vegetables could be related to the thermal degradation of tannins during the process of cooking (Miglio et al, 2008). Similar results in vegetables were also reported by Alajaji and El-Adawy (2006) and Hemmige et al. (2017).

\section{Saponin content}

Cooking vegetables by boiling, air frying and microwave methods significantly reduced the saponin content of vegetables as compared to fresh ones (Figure 6). Saponin content in fresh vegetables ranged from 19.0 to 32.10 $\mathrm{mg} / \mathrm{g}$. The highest saponin content in raw vegetables was observed in spinach $(32.10 \mathrm{mg} / \mathrm{g})$, followed by kale $(24.50 \mathrm{mg} / \mathrm{g})$, beans $(22.30 \mathrm{mg} / \mathrm{g})$, tomatoes $(20.30 \mathrm{mg} / \mathrm{g})$ and carrot $(19.0 \mathrm{mg} / \mathrm{g})$. The saponin content of cooked
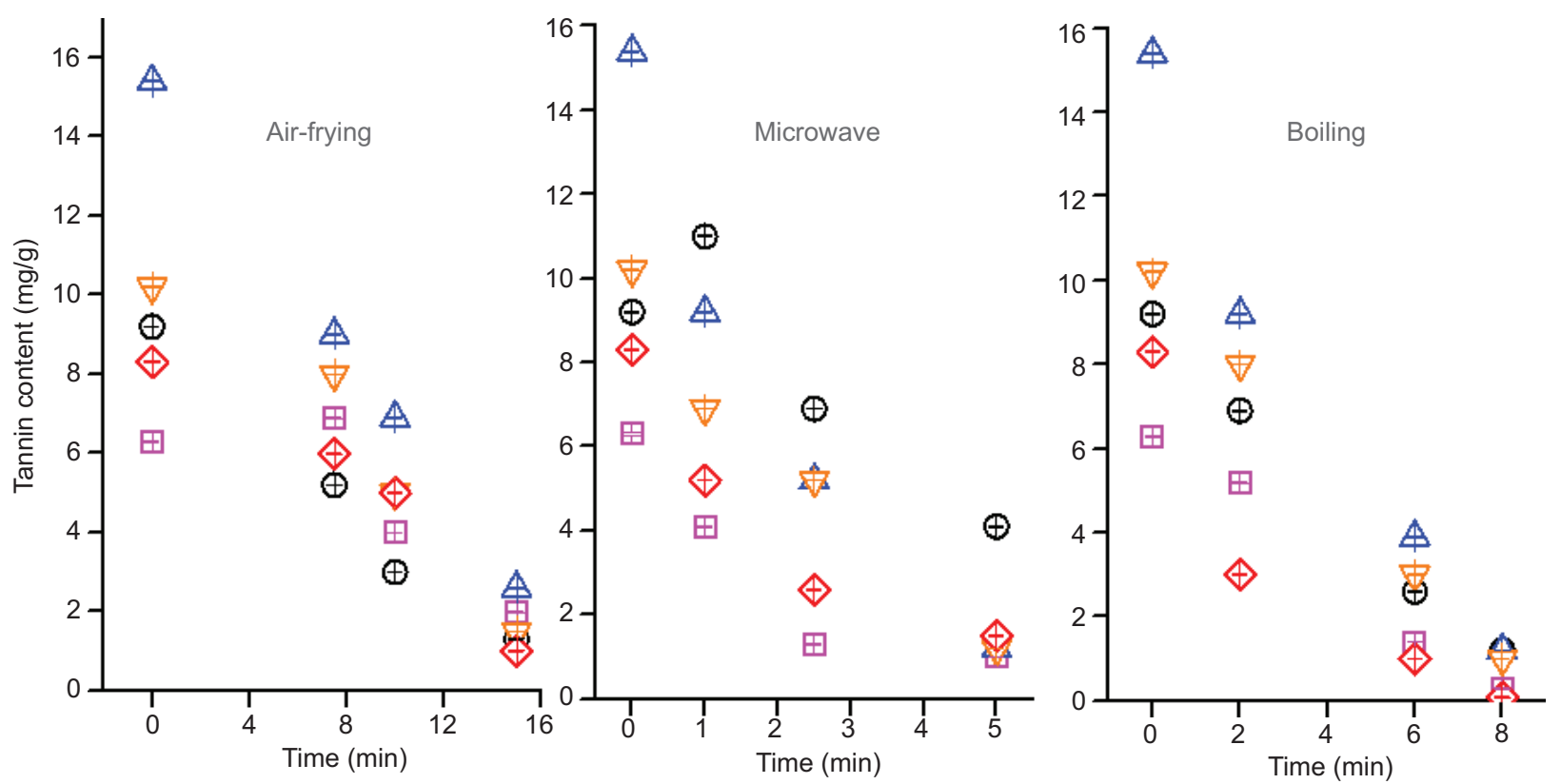

Figure 5. Effect of different cooking methods on the tannin content of kale $(\square)$, spinach $(\bigcirc)$, beans $(\triangle)$, carrot $(\nabla)$ and tomatoes $(\diamond)$.
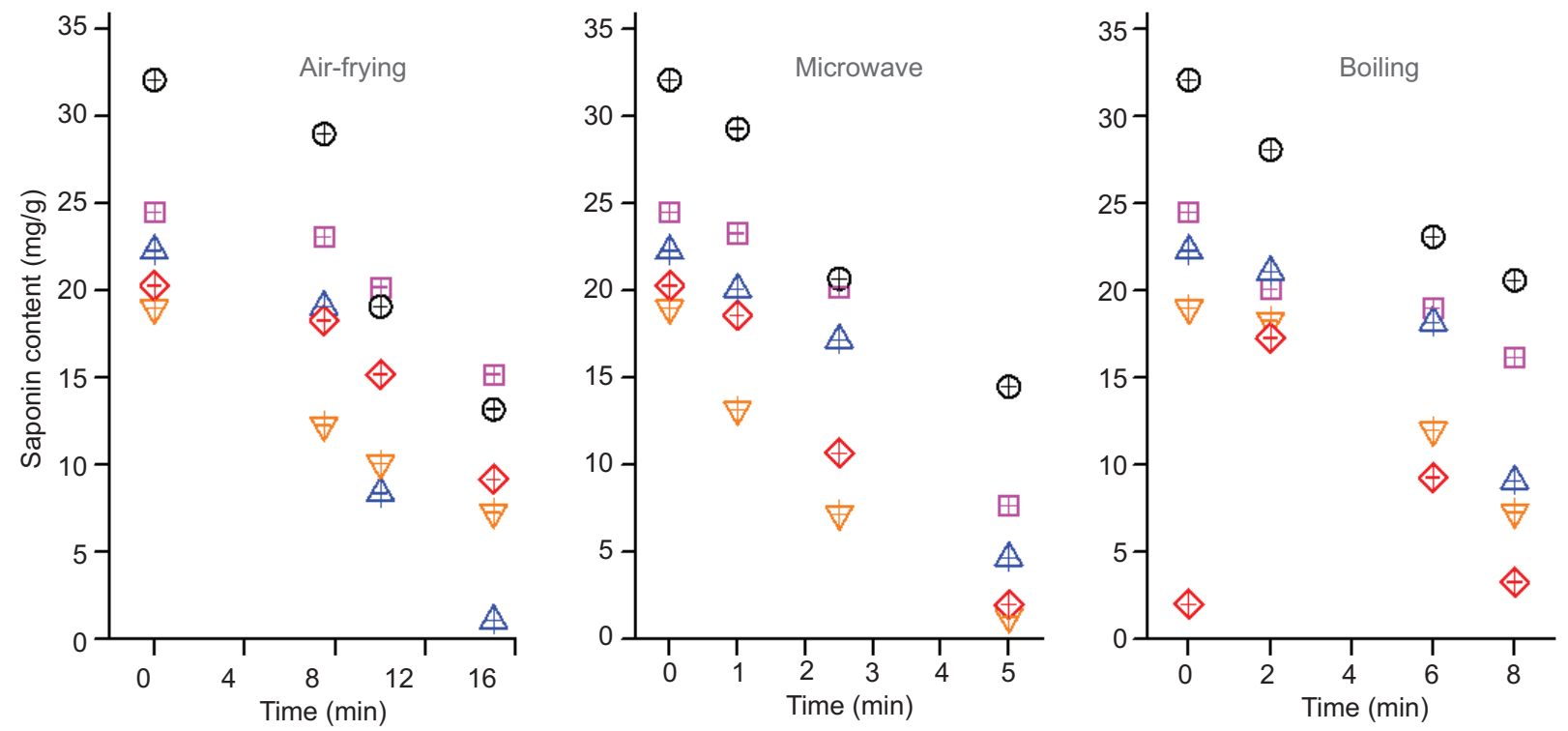

Figure 6. Effect of different cooking methods on saponin content of kale $(\square)$, spinach $(\bigcirc)$, beans $(\triangle)$, carrot $(\nabla)$ and tomatoes $(\diamond)$. 

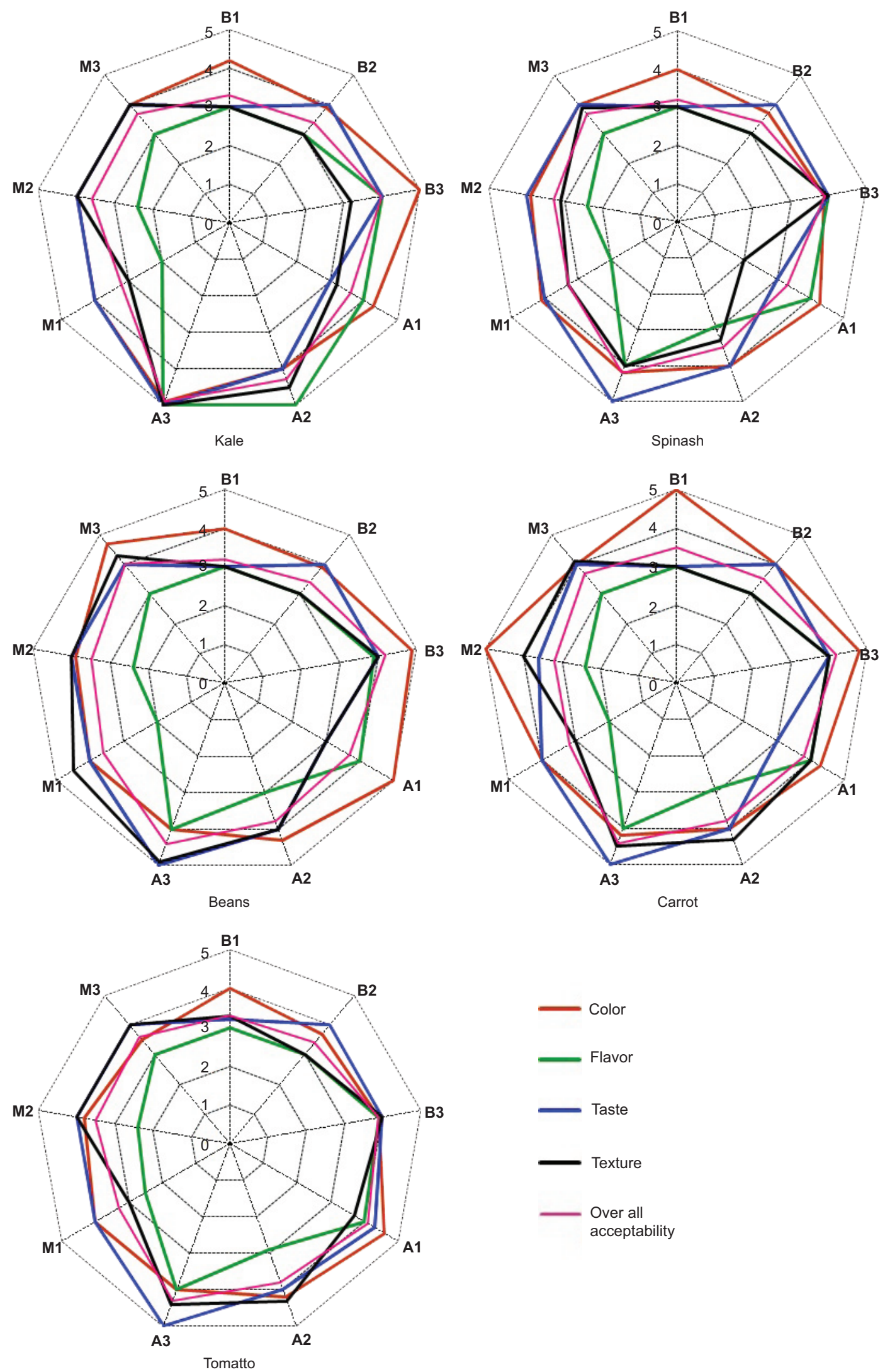

Figure 7. Effect of different cooking methods on the sensory evaluation of vegetables. A1, A2 and A3 are air frying method of cooking vegetables for 7.5, 10 and $15 \mathrm{~min}$; B1, B2 and B3 are boiling method of cooking vegetables for 2, 6 and 8 min; and M1, M2 and M3 are microwave method of cooking vegetables for 1, 2.5 and $5 \mathrm{~min}$. 
vegetables is significantly reduced with boiling, air frying and microwave cooking. Boiling significantly reduced saponin content with an increase in cooking time from 2 to $6 \mathrm{~min}$. Reduction in saponin content at $6 \mathrm{~min}$ of processing time in cooked vegetables was $16.20 \mathrm{mg} / \mathrm{g}$ for kale, $20.60 \mathrm{mg} / \mathrm{g}$ for spinach, $9.10 \mathrm{mg} / \mathrm{g}$ for beans, 7.30 $\mathrm{mg} / \mathrm{g}$ for carrot and $3.30 \mathrm{mg} / \mathrm{g}$ for tomatoes. In air frying, saponin content reduced significantly at the processing time of 7.5, 10 and 15 min. Reduction in saponin content of cooked vegetables at 15 min of air frying was $15.20 \mathrm{mg} / \mathrm{g}$ for kale, $13.2 \mathrm{mg} / \mathrm{g}$ for spinach, $1.10 \mathrm{mg} / \mathrm{g}$ for beans, $7.30 \mathrm{mg} / \mathrm{g}$ for carrot and $9.20 \mathrm{mg} / \mathrm{g}$ for tomatoes. Microwave cooking also decreased saponin content with an optimized cooking time of 1, 2.5 and $5 \mathrm{~min}$. A higher level of reduction in the saponin content of cooked vegetables at $5 \mathrm{~min}$ of processing was as follows: $7.70 \mathrm{mg} / \mathrm{g}$ for kale, $14.50 \mathrm{mg} / \mathrm{g}$ for spinach, $4.70 \mathrm{mg} / \mathrm{g}$ for beans, $1.30 \mathrm{mg} / \mathrm{g}$ for carrot and $2.0 \mathrm{mg} / \mathrm{g}$ for tomatoes. However, microwave and air frying demonstrated a significantly higher reduction in saponin content in cooked vegetables than by the boiling method. Reduction of saponin content could be related to thermal degradation associated with heat supplied to cooked vegetables. This was also observed by Alajaji and El-Adawy (2006), Badifu and Okeke (1992), Hemmige et al. (2017) and Ilelaboye et al. (2013).

\section{Sensory evaluation of boiling, air frying and microwave in cooked vegetables}

The sensory evaluation of vegetables is presented in Figure 7. Cooking of vegetables by boiling, air frying and microwave method improved the sensory property of cooked vegetables, besides increasing bioactive compounds and reducing antinutritional factors. Boiling, air frying and microwave cooking significantly improved the color, flavor, taste and texture of cooked vegetables with an increased duration of optimized cooking time. In boiling, the highest overall acceptability based on color, flavor, taste and texture was observed at $8 \mathrm{~min}$ of cooking for beans (4.2) and carrot (4.2), followed by kale (4.0) and the lowest in the case of spinach (3.9) and tomatoes (3.9). In air frying, the highest overall acceptability observed at 15 min of cooking was as follows: kale (4.9), beans (4.4), carrot (4.4), tomatoes (4.3) and the lowest in spinach (4.2). However, microwave cooking at $5 \mathrm{~min}$ established higher overall acceptability for beans (4.0), followed by carrot (3.7), kale (3.7), spinach (3.7) and the lowest for tomatoes (3.6). The sensory evaluation based on 5-point hedonic scale depicted higher consumer acceptability for air frying than boiling and microwave cooking. Significant improvement in sensory attributes of cooked vegetables by boiling, air frying and microwave cooking could be due to enhancement in color, taste and flavor, and retention of texture during cooking (Nunn et al.,
2006). The sensory scores of cooked vegetables by boiling, air frying and microwave cooking were in the acceptable range, with a high recommendation of processes for preparing semi-processed vegetables with good consumer acceptance. Similar results of sensory evaluation of cooked vegetables have been reported by Şengul et al. (2014), Soomro et al. (2018) and Sultana et al. (2008).

\section{Conclusion}

Vegetables are a rich source of vitamins and phytochemicals, and their consumption in daily diet, besides providing nutrition, helps to fight chronic diseases. Cooked vegetables such as kale, spinach, beans, carrot and tomatoes are a rich source of phytochemicals and antioxidants as compared to fresh ones, which are lower in antinutrients. The cooking of vegetables by boiling, air frying and microwave methods manifests significant improvement in bioactive components. Cooking vegetables significantly increases their phytochemical and antioxidant activity. Boiling, air frying and microwave cooking of vegetables significantly decrease their antinutritional components, thus decreasing the bioavailability of nutrients in vegetables. The stated methods of cooking of selected vegetables increased phenolic content and flavonoids but reduced saponin, tannin and oxalate contents. Phytochemicals had a positive relationship with the cooking time for all three cooking methods. Consumer acceptability of cooked vegetables was highest for the air frying method of cooking as compared to boiling and microwave cooking.

\section{References}

Adams G.G., Imran S., Wang S., Mohammad A., Kok S., Gray D.A., Channell G.A., Moris G.A. and Harding S.E. 2011. The hypoglycaemic effect of pumpkins as anti-diabetic and functional medicines. Food Res. Int. 44:862-867. https://doi.org/10.1016/j. foodres.2011.03.016

Agamy N.F. 2016. Effect of boiling and microwave cooking on some antioxidant compounds in highly consumed vegetables in Egypt. Cent Eur J Oper Res. 2(2):76-84.

Agiriga A.N. and Siwela M. 2018. Effect of thermal processing on the nutritional, antinutrient, and in vitro antioxidant profile of monodoramyristica (gaertn.) dunal seeds. Prev Nutr Food Sci. 23(3):235-244. https://doi.org/10.3746/pnf.2018.23.3.235

Akhtar M.S., Israr B., Nighat Bhatty N. and Ali A. 2014. Effect of cooking on soluble and insoluble oxalate contents in selected pakistani vegetables and beans. Int J Food Prop. 14(1):241-249. https://doi.org/10.1080/10942910903326056

Alajaji S.A. and El-Adawy A. A. 2006. Nutritional composition of chickpea (Cicer arietinum L.) as affected by microwave cooking and other traditional cooking methods. Food Chem. 19(8):806812. https://doi.org/10.1016/j.jfca.2006.03.015 
Aparicio-Fernandez X., Manzo-Bonilla L. and Loarca-Pina G.F. 2005. Comparision of antimutagenic activity of phenolic compounds in newly harvested and stored common beans Phaseolus vulgaris against Aflatoxin B1. J Food Sci. 70:73-78. https://doi. org/10.1111/j.1365-2621.2005.tb09068.x

Association of Official Analytical Chemists (AOAC). 2002. Official Methods of Analysis, 15th edn. AOAC, Washington, DC.

Badifu G.I.O. and Okeke E.M. 1992. Effect of blanching on oxalate, hydrocyanic acid and saponin content of four Nigerian leafy vegetables. J Agric Sci Technol. 2(1):71-75.

Bassey E.E. and Khan M.E. 2015. Proximate composition and phytochemical analysis of Bombax Buonopozense Leaves (Gold coast Bombax). Int J Curr Res Chem Pharm Sci. 2(11):51-56.

Catherwood D.J., Savage G.P., Mason S.M., Scheffer J.J.C. and Douglasc J.A. 2007. Oxalate content of cormels Japanese taro (Colocasia esculenta (L.) Schott) and the effect of cooking. J. Food Compost Anal. 20:147-151. https://doi.org/10.1016/j. jfca.2005.12.012

Chenard C.A., Zimmerman M.B., Smith K.L., Nonnie P.F. and Wahls T.L. 2015. New measured weight for one cup raw kale reduces nutrient intake of individuals following the Wahls diet. Procedia Food Sci. 4:39-47. https://doi.org/10.1016/j. profoo.2015.06.007

Chinma C.E. and Igyor M.A. 2007. Micronutrients and antinutritional contents of selected tropical vegetables grown in southeast. Nigeria Food J. 25:111-116. https://doi.org/10.4314/nifoj. v25i1.33659

Chung H.J., Liu Q., Pauls K.P., Fan M.Z. and Yada R. 2008. In vitro starch digestibility, expected glycemic index and some physicochemical properties of starch and flour from common bean (Phaseolus vulgaris L.) varieties grown in Canada. Food Res Int. 41:869-875. https://doi.org/10.1016/j.foodres.2008. 03.013

Ebrahimzadeh M.A., Pourmorad F. and Bekhradnia A.R. 2008. Iron chelating activity, phenol and flavonoid content of some medicinal plants from Iran. Afr J Biotechnol. 7:3188-3192.

Eliassen A.H., Hendrickson S.J., Brinton L.A., Buring J.E., Campos H., Dai Q. and Hallmans G. 2012. Circulating carotenoids and risk of breast cancer: pooled analysis of eight prospective studies. J Natl Cancer Inst. 104(24):1905-1916. https://doi. org/10.1093/jnci/djs461

Fabbrin A.D.T. and Crosby G.A. 2016. A review of the impact of preparation and cooking on the nutritional quality of vegetables and legumes. Int J Gastron Food Sci. 3:2-11.https://doi. org/10.1016/j.ijgfs.2015.11.001

Ferioli F., Giambanelli E., D’Antuono L.F., Costa H.S., Albuquerque T.G., Silva A.S. and Kocaoglu B. 2013. Comparison of leafy kale populations from Italy, Portugal, and Turkey for their bioactive compound content: phenolics, glucosinolates, carotenoids, and chlorophylls. J Sci Food Agric. 93(14):34783489. https://doi.org/10.1002/jsfa.6253

Ferracane R., Pellegrini N., Visconti A., Graziani G., Chiavaro E., Miglio C. and Fogliano V. 2018. Effects of different cooking methods on the antioxidant profile, antioxidant capacity, and physical characteristics of artichoke. J Agric Food Chem. 56:860-8608. https://doi.org/10.1021/jf800408w
Fiedor J. and Burda K. 2014. Potential role of carotenoids as antioxidants in human health and disease. Nutrients. 6:466-488. https://doi.org/10.3390/nu60204.66.

Fratianni A., D’Agostino A., Niro S., Bufano A., Paura B. and Panfili G. 2021. Loss or gain of lipophilic bioactive compounds in vegetables after domestic cooking. Effect of Steaming and boiling. Foods.10(5):960. https://doi.org/10.3390/foods10050960

Frusciante L., Carli P., Ercolano M.R., Pernice R., Di Matteo A., Fogliano V. and Pellegrini N. 2007. Antioxidant nutritional quality of tomato. Mol Nutr Food Res.1(5):609-617. https://doi. org/10.1002/mnfr.200600158

Geetha K., Hulamani S. and Shivaleela H.B. 2018. Effect of cooking on total antioxidant activity, polyphenols and flavanoid content in commonly consumed vegetables. Int J Curr Microbiol Appl Sci. 7(2):1459-1466. https://doi.org/10.20546/ijcmas.2018.702.176

Ghoora M.D., Babu D.R. and Srividya N. 2020. Nutrient composition, oxalate content and nutritional ranking of ten culinary microgreens. J Food Compost Anal. 91:103495. https://doi. org/10.1016/j.jfca.2020.103495

Granito M., Palolini M. and Perez S. 2008. Polyphenols and antioxidant activity of Phaseolus vulgaris stored under extreme conditions and processed. LWT-Food Sci.Technol. 41:994-999. https://doi.org/10.1016/j.lwt.2007.07.014

Groch W. 2008. Vegetables and vegetable products. In: Belitz.W, H.D., Schieberle G.P. (eds) Food Chemistry. Springer, Berlin, Germany, pp. 770-798.

Hemmige N.H., Abbey L. and Asiedu S.K. 2017. An overview of nutritional and antinutritional factors in green leafy vegetables. Int J Hortic Sci. 1(2):00011. https://doi.org/10.15406/ hij.2017.01.00011

Hossain A., Khatun M.A., Islam M. and Huque R. 2017. Enhancement of antioxidant quality of green leafy vegetables upon different cooking method. Prev Nutr Food Sci. 22(3):216-222.

Ilelaboye N.O.A., Amoo I.A. and Pikuda O.O. 2013. Effect of cooking methods on mineral and antinutrient composition of some green leafy vegetables. Arch Appl Sci Res. 5(3):254-260.

Kaur S., Sharma S., Singh B. and Dar B.N. 2015. Effect of extrusion variables (temperature, moisture) on the antinutrient components of cereal brans. J Food Sci Technol. 52(3):1670-1676. https://doi.org/10.1007/s13197-013-1118-4.

Korus A. and Lisiewska Z. 2011. Effect of preliminary processing and method of preservation on the content of selected antioxidative compounds in kale (Brassica oleracea L. var. acephala) leaves. Food Chem. 129(1):149-154. https://doi.org/10.1016/j. foodchem.2011.04.048

Lin C.H. and Chang C.Y. 2005. Textural change and antioxidant properties of broccoli under different cooking treatments. Food Chem. 90(1-2):9-15. https://doi.org/10.1016/j. foodchem.2004.02.053

Lin L.Z., Harnly J.M., Pastor-Corrales M.S. and Luthria D.L. 2008. The polyphenolic profiles of common beans (Phaseolus vulgaris L.). Food Chem. 107:399-410. https://doi.org/10.1016/j. foodchem.2007.08.038

Mazzeo T., N’Dri D., Chiavaro E., Visconti A., Fogliano V. and Pellegrini N. 2011. Effect of two cooking procedures on 
phytochemical compounds, total antioxidant capacity, and color of selected frozen vegetables. Food Chem. 128:627-633. https:// doi.org/10.1016/j.foodchem.2011.03.070

Miglio C., Chiavaro E., Visconti A., Fogliano V. and Pellegrini N. 2008. Effects of different cooking methods on nutritional and physicochemical characteristics of selected vegetables. J Agric Food Chem. 56(1):139-147. https://doi.org/10.1021/jf072304b

Mirzaei A., Delaviz H. and Mohammadi H. 2014. The effects of cooking methods on antioxidant activity and phenol content in vegetables. World J Pharm Pharm Sci. 3(7):242-252.

Morales F.J. and Babbel M.B. 2002. Antiradical efficiency of Maillard reaction mixtures in a hydrophilic media. J Agric Food Chem. 50:2788-2792. https://doi.org/10.1021/jf011449u

Mulla M. and Ahmed J. 2019. Modulating functional and antioxidant properties of proteins from defatted garden cress (Lepidium sativum) seed meal by Alcalase hydrolysis. J Food Meas Charact. 13(4):3257-3266. https://doi.org/10.1007/s11694-019-00248-8

Nartea A., Fanesi B., Falcone P.M., Pacetti D., Frega N.G. and Lucci P. 2021. Impact of mild oven cooking treatments on carotenoids and tocopherols of cheddar and depurple cauliflower (Brassica oleracea L. var. botrytis). Antioxidants.10(2):196-204. https:// doi.org/10.3390/antiox10020196

Naz S., Anjum M.A., Naqvi S.A.H., Siddique B. and Zulfiqar M.A. 2018. Assessment of proximate, nutritional and mineral contents in some traditional vegetables consumed in Multan, Pakistan. Pak J Agric Sci. 31(4):375-381. https://doi.org/10.17582/journal. pjar/2018/31.4.375.381

Nunn M.D., Giraud D.W., Parkhurst A.M., Hamouz F.L. and Driskell J.A. 2006. Effects of cooking methods on sensory qualities and carotenoid retention in selected vegetables. J Food Qual. 29:445-457. https://doi.org/10.1111/j.1745-4557.2006.00071.x

Obadoni B.O. and Ochuko P.O. 2001. Phytochemical studies and comparative efficacy of crude extracts of some homeostatic plants in Edo and Delta states of Nigeria. Glob J Pure Appl. 8:203-208. https://doi.org/10.4314/gjpas.v8i2.16033

Oboh G. 2005. Effect of blanching on the antioxidant properties of some tropical green leafy vegetables. LWT-Food Sci. Technol. 38(5):513-517. https://doi.org/10.1016/j.lwt.2004.07.007

Oboh G. and Rocha J.B.T. 2007. Antioxidants in foods: a new challenge for food processors. In: Oboh G. and Rocha J.B.T. Leading Edge Antioxidants Research. Nova, New York, NY, pp. 35-64.

Patricia O., Zoue L., Megnanou R.M., Doue R. and Niamke S. 2014. Proximate composition and nutritive value of leafy vegetables consumed in Northern Côte d'Ivoire. Eur Sci J. 10(6):212-227.

Pojer E., Mattivi F., Johnson D., Stockley C.S. 2013. The case for anthocyanin consumption to promote human health: a review. Compr Rev Food Sci Food Saf. 12(5):483-508. https://doi. org/10.1111/1541-4337.12024

Rana M.R., Ahmad H., Sayem A.S.M., Jothi J.S., Hoque M.M. and Rahman M. 2021. Effects of different cooking methods on physicochemical and bioactive compounds of selected green vegetables in north eastern region, Bangladesh. Curr Res Nutr Food Sci. 9(2):628-638. https://doi.org/10.12944/CRNFSJ.9.2.26

Rani E.P. and Fernando R.R.S. 2016. Effect of cooking on total antioxidant activity in selected vegetables. Int J Home Sci. 2(2):218-222.
Rashmi H.B. and Negi P.S. 2020. Phenolic acids from vegetables: a review on processing stability and health benefits. Food Res. Int. 136:109298. https://doi.org/10.1016/j.foodres.2020.109298

Rehman Z.U., Islam M. and Shah W.H. 2003. Effect of microwave and conventional cooking on insoluble dietary fibre components of vegetables. Food Chem. 80:237-240. https://doi.org/10.1016/ S0308-8146(02)00259-5

Rinaldi M., Santi S., Paciulli M., Ganino T., Pellegrini N., Visconti A. and Chiavaro E. 2021. Comparison of physical microstructural and antioxidative properties of pumpkin cubes cooked by conventional, vacuum cooking and sous vide methods. J Sci Food Agric 101(6):2534-2541. https://doi.org/10.1002/jsfa.10880

Rodriguez-Amaya D.B. 1999. Changes in carotenoids during processing and storage of foods. Arch Latinoam Nutr. 49:38-47.

Saikia S., Mahanta C.L. 2013. Effect of steaming, boiling and microwave cooking on the total phenolics, flavonoids and antioxidant properties of different vegetables of Assam, India. Int J Food Sci Nutr 2(3):47-53.

Salamatullah A.M., Ahmed M.A., Alkaltham M.S., Hayat K., Aloumi N.S., Al-Dossari A.M. and Arzoo S. 2021. Effect of air-frying on the bioactive properties of eggplant (Solanum melongena L). Processes. 9(3):435. https://doi.org/10.3390/pr9030435

Şengul M., Yildiz H. and Kavaz A. 2014. The effect of cooking on total polyphenolic content and antioxidant activity of selected vegetables. Int. J. Food Prop. 17(3):481-490. https://doi.org/10. 1080/10942912.2011.619292

Septembre-Malaterre A., Remize F. and Poucheret P. 2018. Fruits and vegetables as a source of nutritional compounds and phytochemicals: changes in bioactive compounds during lactic fermentation. Food Res Int. 104:86-99. https://doi.org/10.1016/j. foodres.2017.09.031

Siddiq M., Ravi R. and Dolan K.D. 2010. Physical and functional characteristics of selected dry bean (Phaseolus vulgaris L.) flour. LWT-Food Sci Technol. 43:232-237. https://doi.org/10.1016/j. lwt.2009.07.009

Singh G., Kawatra A. and Sehgal S. 2001. Nutritional composition of selected green leafy vegetables, herbs and carrots. Plant Foods Hum Nutr. 56:359-364. https://doi.org/10.1023/A:1011873119620

Singh B.K., Sharma S.R. and Singh B. 2009. Heterosis for mineral elements in single cross-hybrids of cabbage (Brassica oleracea var. capitata L.). Sci Hortic.122(1):32-36. https://doi. org/10.1016/j.scienta.2009.04.007

Singleton V.L., Orthofer R. and Lamuela-Raventos R.M. 1999. Analysis of total phenols and other oxidation substrates and antioxidants by means of folin-ciocalteu reagent. Methods Enzymol. 299:152-178. https://doi.org/10.1016/S0076-6879(99)99017-1

Soomro A., Marri A., Shaikh N., Soomro A.H. and Khaskheli SG. 2018. Impact of cooking methods on physicochemical and sensory attributes of apple gourd. J Basic Appl Sci. 14:136-140. https://doi.org/10.6000/1927-5129.2018.14.20

Stewart A.J., Bozonnet S., Mullen W., Jenkins G.I., Lean M.E.J. and Crozier A. 2000. Occurrence of flavonols in tomatoes and tomato-based products. J Agric Food Chem. 48:2663-2669. https:// doi.org/10.1021/jf000070p

Sultana B., Anwar F. and Iqbal S. 2008. Effect of different cooking methods on the antioxidant activity of some 
vegetables from Pakistan. Int J Food Sci. 43:560-567. https://doi. org/10.1111/j.1365-2621.2006.01504.x

Sun T. and Ling F. 2021. Optimization method of microwave drying process parameters for rice. Qual Assur Saf Crop Foods. 13(3):10-20. https://doi.org/10.15586/qas. v13i3.917

Tanaka T., Shnimizu M. and Moriwaki H. 2012. Cancer chemoprevention by carotenoids. Molecules. 17(3):3202-3242. https:// doi.org/10.3390/molecules17033202

Tayebeh B., Soraya K. and Khaneghah A.M. 2021. Antioxidant and antibacterial activity of ethanolic extract of safflower with contrasting seed coat color. Qual Assur Saf Crop Foods. 13(2):94100. https://doi.org/10.15586/qas.v13i2.866

Tepe B. and Ekinci R. 2021. Drying characteristics and some quality parameters of whole jujube (Zizyphus jujuba Mill.) during hot air drying. Ital J Food Sci. 33(1):1-15. https://doi.org/10.15586/ ijfs.v33i1.1947
Wachtel-Galor S., Wong K.W. and Benzie I.F.F. 2008. The effect of cooking on Brassica vegetables. Food Chem. 110(3):706-710. https://doi.org/10.1016/j.foodchem.2008.02.056

Yadav S.K. and Sehgal S. 2003. Effect of domestic processing and cooking on selected antinutrient contents of some green leafy vegetables. Plant Foods Hum Nutr. 58(3):1-11. https://doi. org/10.1023/B:QUAL.0000040359.40043.4f

Zeb A., Haq, A., Murkovic M. 2018. Effects of microwave cooking on carotenoids, phenolic compounds and antioxidant activity of Cichorium intybus L. (chicory) leaves. Eur Food Res Technol. 245:365-374. https://doi.org/10.1007/s00217-018-3168-3

Zhan D. and Hamauzu Y. 2004. Phenolics, ascorbic acid, carotenoids and antioxidant activity of broccoli and their changes during conventional and microwave cooking. Food Chem. 88:503-509. https://doi.org/10.1016/j.foodchem.2004.01.065 